\title{
INFORMACINIŲ IR KOMUNIKACINIŲ TECHNOLOGIJŲ İTAKA SVEIKATOS PRIEŽIŪROS PASLAUGŲ TEIKIMUI
}

\author{
Kęstutis Štaras \\ Mykolo Romerio universiteto Socialinès politikos fakulteto Sociologijos katedra \\ Ateities g. 20 LT-08303 Vilnius, Lietuva \\ Telefonas (+370 5) 2714715 \\ Elektroninis paštas kestutis.staras@pylimas.lt

\section{Monika Mačiulienè} \\ Mykolo Romerio universiteto Socialinès politikos fakulteto \\ Komunikacijos ir informatikos institutas \\ Ateities g. 20 LT-08303 Vilnius, Lietuva \\ Telefonas (+370 5) 2714571 \\ Elektroninis paštas maciuliene@mruni.eu \\ Viktorija Stokaitè \\ Mykolo Romerio universiteto Politikos ir vadybos fakulteto Vadybos institutas \\ Valakupių g. 5 LT-10101 Vilnius, Lietuva \\ Telefonas (+370 5) 2740610 \\ Elektroninis paštas v.stokaite@mruni.eu
}

Pateikta 2013 m. birželio 30 d., parengta spausdinti 2013 m. rugsëjo 25 d.

doi:10.13165/SPV-13-1-5-10

\section{Santrauka}

Straipsnyje nagrinejama informaciniu ir komunikaciniu technologiju (toliau - IKT) įtaka sveikatos priežiūros paslaugų teikimui siekiant išsiaiškinti sveikatos priežiūros specialistu nuomonę. Nagrinejamu aspektu lyginami Všt Centro poliklinikoje 2010 ir 2012 m. atliktu apklausų rezultatai. Atsižvelgiant i IKT paplitima, pritaikymą, populiaruma ir nuolatini kisma, tyrimas pasirinktas tikslingai dèl technologiju pridètinès vertès kūrimo bei ịtakos sveikatos priežiūros įstaigų veiklai. Akcentuotina, kad sparti IKT plètra lèmè įvairiapusiškus pokyčius (naujas organizacines priemones, valdymo procesu bei vadybos kaita), kurie suponavo vidines ir išorines transformacijas asmens sveikatos priežiūros įstaigose. Sveikatos priežiūros įstaigos dèl IKT plètros susiduria su ịvairiais iššūkiais įskaitant inovatyvaus mąstymo, bendradarbiavimo bei sveikatos įstaigos narių sinergijos skatinimo būtinybę. Užsienio šalių analogišku tyrimu rezultatai patvirtina organizacinès komunikacijos svarbą. IKT lemia sveikatos priežiūros istaigu veiklos kismą, todèl atliktas įstaigu specialistų nuomoniu pokyčiu tyrimas yra ypač 
aktualus atsižvelgiant į bendradarbiavimo aspekto būtinybę ir glaudžias sąsajas su organizaciniais informacijos valdymo ir mainu procesais. Straipsnyje taikyti teoriniai literatūros analizès metodai, taip pat atlikta užsieniu šaliu gerosios patirties apžvalga. Empirinio tyrimo metu Všt Centro poliklinikoje 2010 ir $2012 \mathrm{~m}$. atliktos apklausos. Vykdytos anketines apklausos metu 2010 m. apklausti 144 sveikatos priežiūros specialistai, $2012 \mathrm{~m}$. - 252, kurie teikdami asmens sveikatos priežiüros paslaugas savo darbo vietose naudojasi IKT. Remiantis empirinio tyrimo duomenimis, atlikta Všt Centro poliklinikos atvejo analizè. Apklausų metu surinkti duomenys buvo apdoroti SPSSv.19 programiniu paketu. Atlikus tyrimą, atsižvelgiant i sveikatos priežiūros specialistu darbo staža, profesija / specializacija ir kompiuterinį raštinguma, palygintos sveikatos priežiūros specialistu nuomonés apie:

- Istaigoje naudojamu IKT įtaka sveikatos priežiūros paslaugų teikimui;

- IKT ịtaka asmens sveikatos priežiūros paslaugu kokybei ir prieinamumui;

- IKT plètra asmens sveikatos priežiūros įstaigoje;

- IKT diegimo asmens sveikatos priežiūros ìstaigoje svarba, renkantis ją kaip darbovietę.

Straipsnyje, remiantis atlikta mokslinès literatūros analize, sudaryta asmens sveikatos priežiūros specialistu nuomoniu apie IKT ịtaka medicinos paslaugu teikimui tyrimu apžvalga ir išskirti bendri kriterijai.

Reikšminiai žodžiai: sveikatos politika, e. sveikata, informacinès komunikacinès technologijos, asmens sveikatos priežiūros paslaugos.

\section{Ivadas}

Paskutiniaisiais dešimtmečiais IKT plètra bei su tuo susijusių inovacijų sveikatos sektoriuje pokyčiai - pradedant patobulejusiomis diagnostikos, gydymo ir prevencijos programomis bei baigiant tokių koncepcijų kaip telemedicina ir telemonitoringas atsiradimu, sveikatos priežiūra tapo viena konkurencingiausių ir pridètinę vertę kuriančių industrijų pasaulyje. Europos Komisija skatina pokyčius e. sveikatos srityje pasitelkdama Europos Sąjungos struktūrinių fondų finansavimą, remdama mokslinius tyrimus bei iggyvendindama veiksmų planus („E. sveikatos veiksmų planas“ (2004) $)^{1}$, „Pirmaujančios rinkos iniciatyva“ $(2007)^{2}$, „E. sveikatos veiksmų planas 2012-2020“3 (2012) prisideda prie teigiamų pokyčių valstybių narių sveikatos politikoje. P. Hassenteufelo teigimu, neišvengiamai vyksta netiesioginė sveikatos sistemų europeizacija per bendrų standartų diegimą, o žinių, gerosios praktikos plètra gali būti traktuojama kognityvine (tiek vertikalia, tiek horizontalia) europeizacija ${ }^{4}$. Vis dèlto reikia pripažinti, kad e. sveikatos plètra ir pritaikomumas toliau laikomas šalių narių nacionaline prerogatyva, todèl valstybès

1 Commission of the European Communities. E-Health - making healthcare better for European citizens: An action plan for a European e-Health Area. SEC (2004) 539, COM (2004) 356 final, Brussels, 30.4.2004.

2 Europos Bendrijų Komisija. Europos pirmaujančios rinkos iniciatyva [interaktyvus]. 2007 [žiūrèta 2013-05-30]. <http://eur-lex.europa.eu/Notice.do?mode=dbl\&lang=lt\&ihmlang=lt\&lng1=lt,lt\&lng2= bg,cs,da,de,el,en,es,et,fi,fr,hu,it,lt,lv,mt,nl,pl,pt,ro,sk,sl,sv,\&val=461939:cs>.

3 Europos Komisijos komunikatas Europos Parlamentui, Tarybai, Europos ekonomikos ir socialiniu reikalų komitetui ir Regionų komitetui 2012-2020 m. E. sveikatos veiksmų planas. Novatoriška sveikatos priežiūra XXI amžiui [interaktyvus]. 2012 [žiūrèta 2013-05-30]. <http://eur-lex.europa.eu/ LexUriServ/LexUriServ.do?uri=COM:2012:0736:FIN:LT:HTML>.

4 Hassenteufel, P. Quelle européanisation des systèmes de santé ? Informations sociales [interaktyvus]. 2013, 1(175): 48-59 [žiūrèta 2013-05-30]. <www.cairn.info/revue-informations-sociales-2013-1page- $48 . h t m>$. 
narès kurdamos strategijas atitinkamai nustato sveikatos informacinių sistemų vystymą, ligoninių aprūpinimą kompiuterine ir programine ịranga bei medicinos paslaugų teikimą naudojant e. sveikatos sprendimus. IKT plètra sveikatos priežiūros srityje lèmé paslaugų augimą ir diferenciaciją, todèl nenuostabu, kad sveikatos sektoriaus atstovai neišvengiamai susiduria su gausios informacijos rinkimu, apdorojimu bei sklaida, t. y. tampa vis labiau priklausomi nuo IKT kasdieniniame darbe.

Atsižvelgiant ị tai, kad ,tikroji technologijų galia pasireiškia ne gerinant senus procesus, bet sudarant sąlygas organizacijoms sulaužyti nusistovejjusias taisykles ir sukurti naują darbo pobūdị, t. y. persikonfigūruoti“" ${ }^{\text {"5 }}$, sveikatos priežiūros specialistų darbo pobūdžio kismas, susijęs su jų ịtraukimu ị sprendimų prièmimą, manoma, tiesiogiai turi ịtakos sveikatos paslaugų kokybès gerinimui ${ }^{6}$. XXI a. pradžioje sveikatos įstaigos tiek Lietuvos, tiek Europos ir tarptautiniu mastu susiduria su aibe iššūkių kaip šių pokyčių padariniais. Vienas jų - augantys vartotojų poreikiai. M. Hardey teigimu, interneto ir IKT dèka sveikatos sritis nebėra tik sveikatos priežiūros specialistų rankose, bet vis sparčiau perduodama vartotojų žinion ${ }^{7}$. Dèl šios priežasties akcentuotinas sveikatos priežiūros įstaigų darbuotojų nuomonių tyrimų poreikis siekiant išsiaiškinti pagrindinius kliuvinius bei surasti efektyvius problemų sprendimo būdus, užtikrinančius, kad analogiškos šiandieninėje praktikoje egzistuojančios problemos nepasikartos ateityje.

Atsižvelgiant ị tai iškeltas straipsnio tikslas - palyginti Lietuvos ir užsienio šalių sveikatos priežiūros specialistų nuomones apie IKT ịtaką sveikatos priežiūros paslaugų teikimui. Iškeltam tikslui pasiekti atlikta mokslinès literatūros, užsienio šalių gerosios patirties apžvalga leido išskirti bendrus empirinio tyrimo, kuris buvo atliktas Všt Centro poliklinika 2010 ir 2012 metais, kriterijus. Tyrimo rezultatus palyginus su užsienio šalių analogiškų tyrimų rezultatais išskirti unifikuoti dèsningumai.

\section{Tyrimo poreikio analizè}

E. sveikatos sistemų diegimas daro tiesioginị poveikị sveikatos priežiūros ịstaigų efektyvumui, teikiamų medicinos paslaugų kokybei bei pacientų saugumui lygiagrečiai mažinant kaštus bei klaidų tikimybę. B. Rahimi konstatuoja, kad nepaisant didelių investicijų i IKT nèra ịtikinamų tokių sistemų naudos įrodymų. Pasak autoriaus, tyrimų ir studijų, pabrèžiančių e. sveikatos sistemų diegimo ir naudojimo poveikius, publikavimas prisidètų prie empiriniais duomenimis grịstos sveikatos informatikos atsiradimo. Tokie duomenys galètu būti naudojami kaip platforma politikos formuotojams, vadovams bei medicinos personalui priimant sprendimus ${ }^{8}$. Kaip rodo OECD (Organisation for Economic Co-Operation and Development) $2010 \mathrm{~m}$. atlikta analizè, IKT nauda ir ịtaka sveikatos apsaugos srityje yra sunkiai pamatuojama dèl ịvairių priežasčių. Viena jų - empirinių duomenų trūkumas, kadangi nèra bendros sistemos ir unifikuotų indikatorių ${ }^{9}$. Atsižvelgiant ị tai, kad šios kliūtys neleidžia

Hammer, M.; Champy, J. Lereengineering. Paris, Dunod, 1993.

6 Beuscart, R.; Chazard, E.; Duchêne, J.; Ficheur, G.; Renard, J.-M.; Rialle, V.; Souf, N. La e-Santé. Informatique médicale, e-Santé 2013, p. 437-461.

7 Hardey, M. Internet et société : reconfigurations du patient et de la médecine ? Sciences sociales et santé. 2004, 22 (22-1): 21-43.

8 Rahimi, B. ImplementationofHealthInformationSystems, Linköping Studiesin Scienceand Technology. Thesis, 2008, p. 1387.

9 Organisation for Economic Co-operationand Development. 2010. Improving Health Secto rEfficiency: The Role ofInformationand Communication Technologies. OECD Health Policy Studies. Paris: OECD Publishing [interaktyvus]. Accessed February 16, 2011 [žiūrèta 2013-05-30]. <http://www.oecd.org/do cument/61/0,3746,en_2649_33929_45501565_1_1_1_1,00.html>. 
atlikti išsamesnių tyrimų ir lyginamosios analizès, t. y. pamatuoti IKT ịtakos, laiko ir tęstinumo atžvilgiu, dèl unifikuotų indikatorių trūkumo, atlikus mokslinès literatūros apžvalgą, išskirti teigiamai sistemas veikiantys bendrieji faktoriai.

Palyginus $2012 \mathrm{~m} .{ }^{10}, 2010 \mathrm{~m} \cdot{ }^{11}, 2007 \mathrm{~m} .{ }^{12}$ ir $2004 \mathrm{~m} \cdot .^{13}$ atliktus tyrimus nustatyta, kad nuomonè dèl IKT ịtakos sveikatos priežiūros paslaugų teikimui kiekvienu atveju tiriama skirtingai. Apibendrinus atliktus tyrimus konstatuotinas visiškas ir (arba) dalinis kategorijų nesutapimas (respondentų amžius, naudojimosi internetu dažnis (darbo ir ne tik metu), kompiuterinio raštingumo lygmuo, darbo stažas, lytis, šeiminè padètis ir kt.). Dèl minètų priežasčių ribotai atliekami skirtingose šalyse atliktų tyrimų lyginimai, kurie būtų ypač aktualūs ne tik siekiant išskirti teigiamai sistemas veikiančius bendruosius faktorius, bet ir skatintų gerosios praktikos pavyzdžių sklaidą. Remiantis užsienio šalių gerąja patirtimi, siekiant Centro poliklinikoje 2010 ir 2012 m. atliktos apklausos rezultatus palyginti su užsienio šalyse atliktų tyrimų rezultatais, atitinkamai sudarytas klausimynas. Itraukti kriterijai padès išsiaiškinti ir vèliau palyginti, ar nuomonè dèl IKT įtakos sveikatos priežiūros paslaugų teikimui priklauso nuo respondentų amžiaus, naudojimosi internetu dažnio, kompiuterinio raštingumo lygmens, darbo stažo.

Dar 1993 m. Davis ${ }^{14}$ nurodè, kad nepaisant technologijos efektyvumo ir veiksmingumo, sẻkmingas pritaikymas priklauso nuo sistemos vartotojų požiūrio. Šiam teiginiui pritariama ir mokslinejje literatūroje, nagrinejjančioje IKT pritaikomumą e. sveikatos srityje. Hubner $^{15}$ ir Poon ${ }^{16}$ konstatuoja, kad IKT pritaikymas organizacijos veikloje priklauso nuo žmogiškojo faktoriaus. Lewis et al. ${ }^{17}$ nurodo, kad IKT sprendimų nauda ir poveikis priklauso nuo to, kaip šie sprendimai atitinka individualių vartotojų poreikius jų vykdomoje veikloje, kuri savo ruožtu prisideda prie visos organizacijos veiklos efektyvumo didinimo. Ši teiginị patvirtina Šiaurès Airijos sveikatos, socialinių paslaugų ir viešojo saugumo departamento ${ }^{18}$ atlikto tyrimo išvados. Studijos autoriai nurodo, kad nors svarbiausius sprendimus priima sveikatos priežiūros ịstaigų vadovai, projektų sẻkmė dažniausiai priklauso nuo individualaus

${ }_{10}$ Accenture Connected Health: TheDrive to Integrated Healthcare Delivery [interaktyvus]. 2012 [žiūrèta 2013-05-30]. <http://nstore.accenture.com/acn_com/PDF/Accenture-Connected-HealthGlobal-Report-Web.pdf\#zoom $=50<20130601>$.

11 Vozikis, A.; Ypofanti, M.; Papadopoulos, I. Attitudestowardstheuseofinformationandcommunicat iontechnologies (ICT) at work: Findingsfromthehealth care sectorinGreece. Journalof Economicand Business. 2010, 60(1-2).

12 Department of Health, Social Services and Public Safety: ICT Training Group (2007) Knowledge, Skilland Attitudeof NI DHSSPS HealthcareProfessionalstowardsInformationandCommunicationTechno logy: Reportof a Northern Ireland Survey. DHSSPS, Belfast [interaktyvus]. [žiūrèta 2013-05-30]. <www. dhsspsni.gov.uk>.

13 Lorenzo, S.; Mira, J. J. Are Spanishphysiciansready to take advantageofthe Internet? World Hospitals And Health Services: The Official Journa lOf The International Hospital Federation [World Hosp Health Serv]. 2004, 40(3): 31-35, 41-43.

14 Davis, F. User acceptance of information technology: system characteristics, user perceptions and behavioural impacts. International Journal of Man-Machine Studies. 1993, 38: 475-487.

15 Hubner, Ur. IT adoption of clinical information systems in Austrian and German hospitals: results of a comparative survey with a focus on nursing. BMC Medical Informatics and Decision Making. 2010, 10(8): 1-12.

16 Poon, E. Assessing the level of healthcare information technology adoption in the United States: a snapsho. Medical Informatics and Design. 2006, 6(1).

17 Lewis, W.; Agarwal, R.; Sambamurthy, V. Sourcesof Influenceson Beliefsabout Information Technology Use: An Empirical Studyof Knowledge Workers. MIS Quarterly. 2003, 27(4): 657-678.

18 Suppra note 12. 
įsitraukimo. Legris et al..$^{19}$ savo straipsnyje nurodo, kad mokslininkai jau nuo 1970-ųjų telkia pastangas ieškodami faktorių, kurie palengvintų IKT integraciją organizacijose. Ward et al. ${ }^{20}$ atliktas tyrimas apžvelgia egzistuojančią literatūrą, nagrinejjančią sveikatos apsaugos personalo nuomonę apie IKT. Tyrimo rezultatai atskleidžia didejjantị mokslinès literatūros šaltinių, kuriuose rašoma apie sveikatos informatikos aspektus, susijusius su sveikatos politika, techninès bei programinès ịrangos diegimu ir iggyvendinimu, skaičių. Kaip vienas iš veiksnių diegiant IKT ịvardinamas darbuotojų požiūris. Rahimi et al. ${ }^{21}$ atlikta struktūrizuota kokybinè metaanalizè leido išskirti pagrindinius IKT plètrą sveikatos sektoriuje lemiančius faktorius. Tyrimo rezultatuose autoriai identifikuoja tris grupes faktorių, kurie yra svarbūs diegiant tokio tipo sistemas: (1) ilgalaikès strategijos sritis (vadovybès ịsitraukimas, motyvacija, sistemos efektyvumo stebejjimas, poreikių analizè); (2) vidutinès trukmès strategijos sritis (išsilavinimas ir mokymai, igyvendinimo procesas ir metodai, sistemų integracija, darbų eigos / srauto integracija); (3) kasdienių darbų sritis (pasitikejjimas, vartotojų įsitraukimas, techninis sistemos veikimas).

D. Ndiaye atlikta komunikacijos analizè sveikatos sektoriuje ir komunikacijos ittaka IKT plètrai tik patvirtina iškeltą nuostatą, kad suinteresuotųjų pusių i̇traukimas tiesiogiai susiję su sveikatos įstaigos funkcionavimo gerinimu bei klinikinès praktikos tobulinimu ${ }^{22}$. Sparti IKT plètra iš esmès keičia paslaugų spektrą bei medicinos praktiką. Šie procesai inovatyvios praktikos sveikatos priežiūros ístaigose yra horizontalaus darbo pobūdžio modelio diegimo prielaida, skatinant darbuotojų autonomiją, išryškinant kolektyvinès dinamikos būtinybę. Kvebeke (Kanada) sveikatos ịstaigose atlikus IKT naudojimo sveikatos srityje tyrimą, konstatuojama IKT galimo ir pageidaujamo poveikio konfrontacija. Sprendimus priimančių asmenų ir sveikatos paslaugas teikiančių asmenų nuomonių nesutapimas sukelia ịvairių problemų, todèl akcentuojama sveikatos specialistų nuomonių dèl IKT diegimo bei su šiuo procesu susijusių pokyčių ir nuomonių tyrimų būtinybè. S. Grosjeano ir L. Bonneville'io nuomone, siekiant geriau suprasti, kokị poveikị IKT diegimas ir naudojimas daro sveikatos priežiūros ị̂staigoms, pirmiausia derètų atsižvelgti ị sveikatos priežiūros ịstaigų darbuotojų nuomonę bei skatinti dinaminius pokyčius nesukuriant vidinès ịtampos, kadangi IKT pačios savaime nelemia sveikatos priežiūros ịstaigos veiklos ${ }^{23}$. Akcentuotina vadybinè logika, skatinanti keitimąsi informacija, savitarpio supratimą bei savarankiškumą, todèl Centro poliklinikoje atliktas sveikatos priežiūros specialistų nuomonių apie IKT ịtaką medicinos paslaugų teikimui 2010 ir $2012 \mathrm{~m}$. palyginimas prisideda prie IKT diegimo ir naudojimo konkrečioje sveikatos priežiūros įstaigoje supratimo. Straipsnyje tyrimo rezultatai lyginami su tarptautiniais pavyzdžiais, siekiant išsamiai atlikti tyrimo analizę, vertinimą bei, palyginus skirtingų šalių atvejus, pateikti unifikuotus dèsningumus.

19 Legris, P.; Ingham, J.; Collerette, P. Why do people use information technology: A critical review of the technology acceptance model. Information \& Management. 2003, 40: 191-204.

20 Ward, R.; Stevens, C.; Brentnall, P.; Briddon, J. The attitudes of health care staff to information technology: a comprehensive review of the research literature. Health Info Libr J. 2008, 25(2): 81-97.

${ }_{21}$ Rahimi, B. Implementation of Health Information Systems. Linköping Studies in Science and Technology. Thesis 2008, p. 1387.

22 Ndiaye, Diarra. Analysecommunicationnelledessystèmes d'informationdanslesecteur de lasanté (2000-2012): l'exemple de l'implantation de deux logiciels dans les pratiques de la clinique mutualiste La Sagesse de Rennes - 2013 [interaktyvus]. [žiūrèta 2013-05-30]. <http://tel.archives-ouvertes.fr/ docs/00/81/81/88/PDF/2013theseNdiayeDpartielle.pdf $>$.

23 Grosjean, S.; Bonneville, L. Logiques d'implantation des TIC dans le secteur de la santé. Revue française de gestion . [interaktyvus]. 2007, 3 ( $\mathrm{n}^{\circ}$ 172): 145-157 [žiūrèta 2013-05-30]. <www.cairn.info/revuefrancaise-de-gestion-2007-3-page-145.htm>. 


\section{Sveikatos priežiū ros specialistų nuomonių apie informacinių ir komunikacinių technologijų ịtaką sveikatos priežiūros paslaugų teikimui}

\subsection{Tyrimo metodika}

Siekiant palyginti Lietuvos ir užsienio šalių sveikatos priežiūros specialistų nuomones apie IKT ịtaką sveikatos priežiūros paslaugų teikimui, $2010 \mathrm{~m}$. ir pakartotinai $2012 \mathrm{~m}$. Všt Centro poliklinikoje buvo atliktos anketinès apklausos. Respondentai buvo apklausti raštu - 2010 m. apklausti 144 respondentai, 2012 m. - apklausti 252 sveikatos priežiūros paslaugas teikiantys specialistai, kurie teikdami asmens sveikatos priežiūros paslaugas savo darbo vietose naudojasi IKT. Anketų grịžtamumas 2010 m. sudarė 72 proc., 2012 m. - 84 proc. Tyrimuose naudota imtis reprezentuoja Všt Centro poliklinikos darbuotojų populiaciją ir struktūrą. Respondentams buvo pateikti 2010 m. tyrime naudoti klausimynai, kuriuose buvo teiraujamasi demografinių duomenų (amžius, lytis, specialybė, stažas) bei sveikatos priežiūros specialistų nuomonès apie IKT ịtaką asmens sveikatos priežiūros paslaugų teikimui, prieinamumui ir kokybei, IKT plètrą sveikatos priežiūros įstaigoje, IKT diegimo sveikatos priežiūros ịstaigoje svarbą, renkantis ją kaip darbovietę ${ }^{24}$. Gauti duomenys lyginami vertinant specialybės, darbo stažo ir kompiuterinio raštingumo tarpusavio skirtumus.

Apklausų metu surinkti duomenys buvo apdoroti naudojantis SPSSv.19 programiniu paketu. Atsakymų dažniams apskaičiuoti taip pat naudota „frequencies“ procedūra, kuri parodo atvejų skaičių bei atsakymo varianto lyginamąji svorị (procentą), lyginamąji svorị, atmetus neatsakiusius ị klausimą respondentus (tikrąji procentą)25 (Pukènas, 2005).

Skirstinių normalumo dèsnis buvo nustatomas remiantis vienos imties Kolmogorovo ir Smirnovo testu(1-Sample Kolmogorov-Smirnov test). Skirstinio normalumo hipoteze atmesta, jei nustatytas $\mathrm{p}>0,05$. Nustačius nenormaliuosius skirstinius, analizuojant naudoti neparametriniai kriterijai. Atsakymų dažnio pasiskirstymo skirtumui tarp diskrečių (nominalių ir ordinalių) požymių statistiniam reikšmingumui ịvertinti pasirinktas neparametrinis kriterijus - Pirsono chi kvadratas $\left(\chi^{2}\right)$ su 95 proc. tikimybe, t. y. laikoma, kad skirtumas statistiškai reikšmingas, kai p < 0,05 (Chava et al., 1992). Statistinių-koreliacinių ryšių stiprumui (intervaliniams kintamiesiems be skirstinio normalumo prielaidos ir ranginiams kintamiesiems) bei krypčiai tarp nesimetriškų tolydžių dydžių nustatyti pasirinktas neparametrinis Spirmeno koreliacijos koeficientas (rho), kai $\mathrm{p}<0,05$.

\subsection{Tyrimo dalyvių socialinès demografinès charakteristikos}

Tyrime dalyvavo 396 Centro poliklinikos darbuotojai, teikiantys asmens sveikatos priežiūros paslaugas. 144 darbuotojai buvo apklausti $2010 \mathrm{~m}$. vykdytoje apklausoje (36,4 proc. visų tyrime dalyvavusių darbuotojų), 252 darbuotojai buvo apklausti 2012 m. vykdytoje apklausoje (63,6 proc. visų tyrime dalyvavusių darbuotojų). Tyrime dalyvavusių darbuotojų pasiskirstymas pagal profesiją / specializaciją: 59,4 proc. - slaugytojai, 16,8 proc. - gydytojai specialistai ir 23,8 proc. šeimos gydytojai; pagal lyti - 94,7 proc. moterys ir 5,3 proc. vyrai;

24 Štaras, K. Informaciniu technologijų įtaka sveikatos priežiūros įstaigos veiklos efektyvumui: analizé, vertinimas, veiksmingumas. Daktaro disertacija. Socialiniai mokslai. Vilnius: Mykolo Romerio universiteto Leidybos centras, 2011.

25 Pukenas, K. Sportiniu tyrimy duomenu analize SPSS programa. Kaunas: Lietuvos kūno kultūros akademija, 2005. 
darbo stažą - iki $3 \mathrm{~m}$. darbo stažą turintys respondentai sudarè 6,1 proc., 4-10 m. - 9,7 proc., 1-20 m. - 18,9 proc., 21 m. ir daugiau - 65,2 proc.

Apklausoje dalyvavę darbuotojai suskirstyti ị 5 amžiaus grupes: 1 grupè - iki 30 m. - 9,4 proc. visų apklausoje dalyvavusių respondentų; 2 grupè $-31-40 \mathrm{~m}$. amžiaus $-18,8$ proc. visų apklausoje dalyvavusių respondentų; 3 grupe - 41-50 m. - 27,7 proc. visų apklausoje dalyvavusių respondentų; 4 grupé - 51-60 m. - 29,2 proc. visų apklausoje dalyvavusių respondentų; 5 grupè $-61 \mathrm{~m}$. ir vyresnio amžiaus - 15 proc. visų apklausoje dalyvavusių respondentų.

Paklausus poliklinikų darbuotojų, teikiančių asmens sveikatos priežiūros paslaugas, kaip jie patys vertina savo kompiuterinị raštingumą, nustatyta, kad dauguma (46,1 proc. visų apklaustųjų) savo kompiuterinị raštingumą vertina kaip vidutinị ir 35,9 proc. kaip pakankamą. 9,7 proc. darbuotojų nurodè, kad jų kompiuterinis raštingumas yra labai aukštas, 8,4 proc. respondentų manè, kad jų kompiuterinis raštingumas yra silpnas (1 lentelè).

1 lentelè. Sveikatos priežiūros specialistų pasiskirstymas pagal socialinius demografinius požymius, 2010 ir $2012 \mathrm{~m}$.

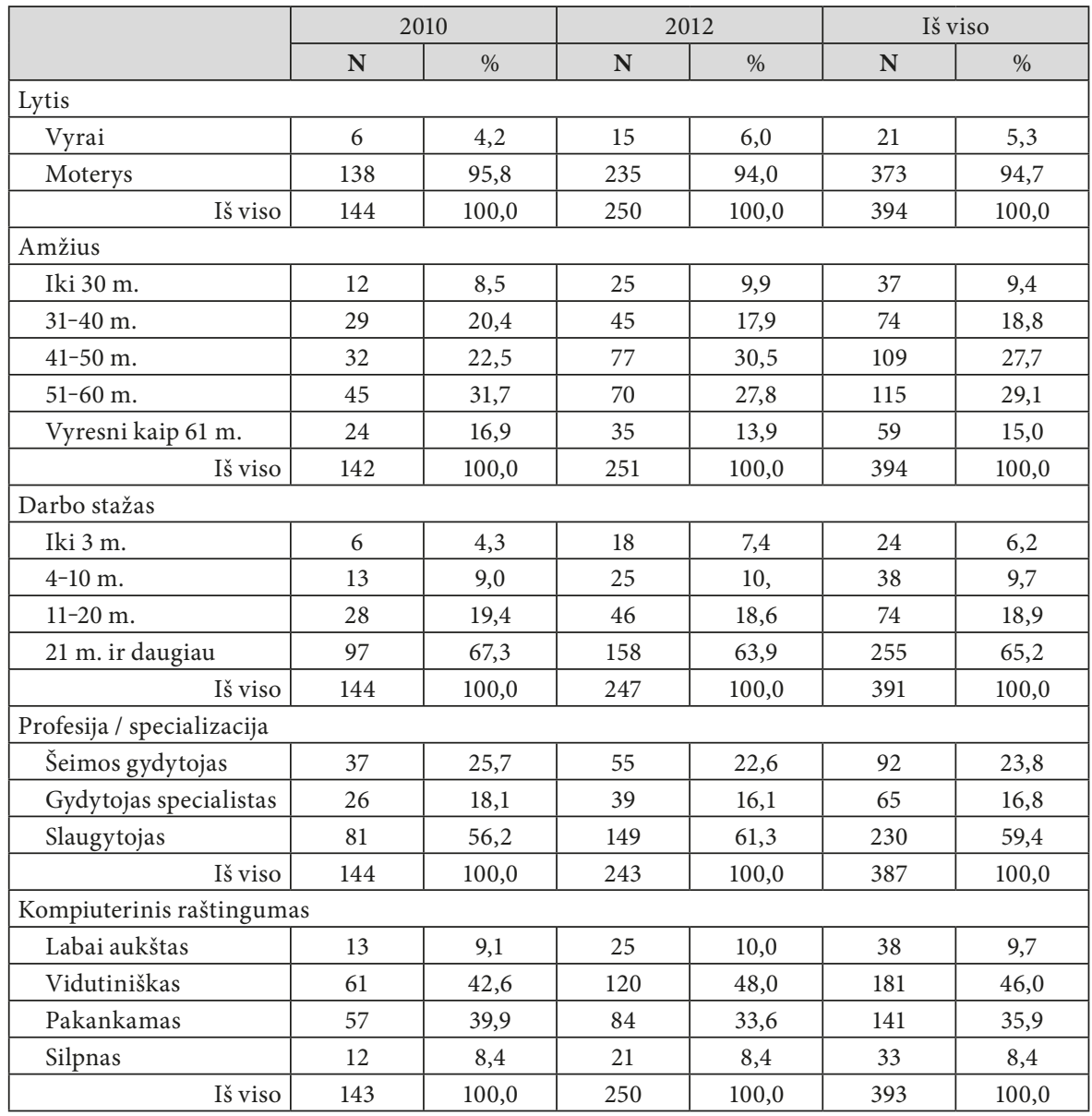




\subsection{Tyrimo rezultatai}

Siekiant išsiaiškinti darbuotojų, teikiančių asmens sveikatos priežiūros paslaugas, nuomonę apie IKT naudojimą, darbuotojams buvo užduotas klausimas, ar naudojimasis IKT darbo vietoje palengvina sveikatos priežiūros paslaugų teikimą. $2012 \mathrm{~m}$. 45,2 proc. apklaustų darbuotojų nurodė, kad darbo vietoje naudojamos IKT labai palengvina sveikatos priežiūros paslaugų teikimą, tuo tarpu 2010 m., kad labai palengvina sveikatos priežiūros paslaugų teikimą, nurodè 57 proc. apklaustųjų. Lyginant su 2010 m., daugiau respondentų nurodè, kad IKT sveikatos priežiūros paslaugų teikimą palengvina vidutiniškai ir iš dalies (po 23,4 proc. 2012 m., 16,9 proc. ir 22,5 proc. 2010 m.).

Vertinant darbuotojų atsakymus pagal darbo stažą, nustatytas statistiškai reikšmingas skirtumas 21 ir daugiau metų darbo stažą turinčių darbuotojų grupejje. $2010 \mathrm{~m}$. apklausoje, kad IKT palengvina sveikatos priežiūros paslaugų teikimą, nurode daugiau nei pusè respondentų, $2012 \mathrm{~m}$. tokios nuomonès buvo 35,4 proc. respondentų $\left(\chi^{2}=10,34, \mathbf{d f}=\mathbf{4}, \mathbf{p}<\mathbf{0 , 0 5}\right)$ (1 pav.).

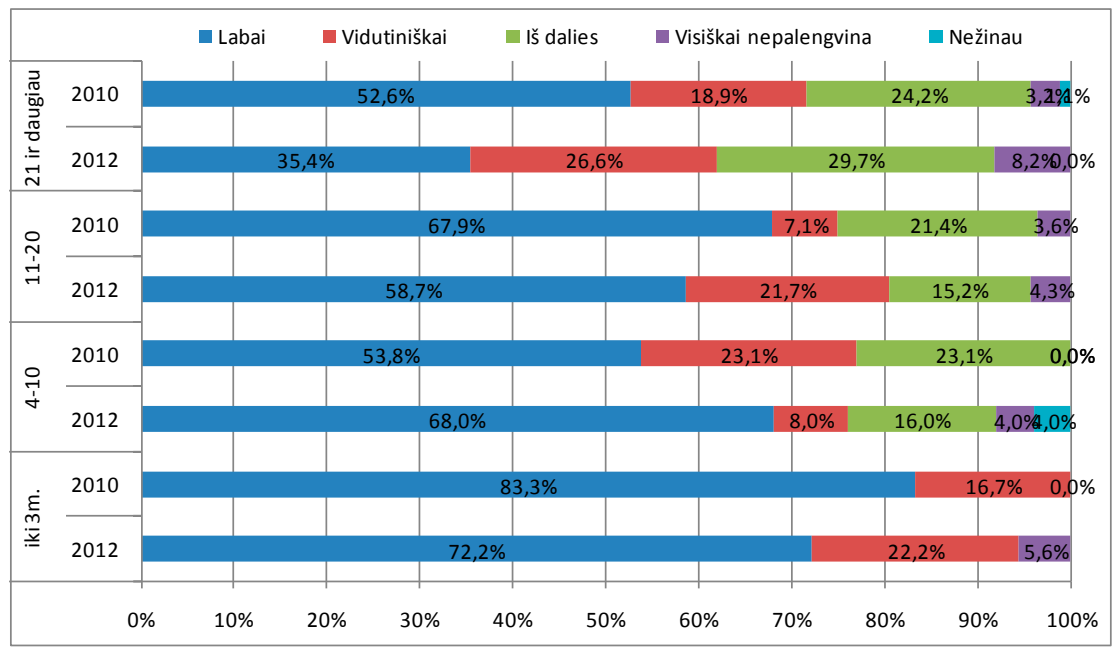

1 pav. Nuomonių, ar naudojimasis IKT palengvina sveikatos priežiūros paslaugų teikimą, pasiskirstymas pagal darbo stažą

Pasiskirstymo pagal darbo stažą aspektu Centro poliklinikoje atlikto tyrimo duomenys sutapo su Graikijoje atlikto tyrimo, kuriame 233 darbuotojams buvo užduodamas analogiškas klausimas, rezultatais. Tyrimo išvadose konstatuojama, kad darbo stažas koreliuoja su teigiamu požiūriu ị naudojimąsi $\mathrm{IKT}^{26}$. Pastebimas bendras dèsningumas - nauji darbuotojai, turintys mažesnị darbo stažą, palankiau vertina IKT, ir didesnis procentas mažesnị darbo stažą turinčių respondentų mano, kad naudojimasis IKT palengvina sveikatos priežiūros paslaugų teikimą.

26 Vozikis, A.; Ypofanti, M.; Papadopoulos, I., supra note 11. 
Analizuojant atsakymus ị klausimą pagal respondentų savo kompiuterinio raštingumo vertinimą, 2010 ir 2012 m. nustatytas statistiškai reikšmingas skirtumas tarp darbuotojų, kurie savo kompiuterinị raštingumą vertino kaip labai aukštą $\left(\chi^{2}=\mathbf{8 , 3 7 9}, \mathbf{d f}=3, \mathbf{p}<\mathbf{0 , 0 5}\right)$ ir vidutinišką $\left(\chi^{2}=\mathbf{8}, 399, \mathbf{d f}=3, \mathbf{p}<\mathbf{0 , 0 5}\right)$. Respondentai, savo kompiuterinị raštingumą vertinę kaip labai aukštą, dažniau teigé, kad IKT naudojamos darbo vietoje labai palengvina sveikatos priežiūros paslaugų teikimą. 2010 m. taip manè 61,5 proc., $2012 \mathrm{~m}$. - 96 proc. respondentų. Taip pat ši IKT privalumą nurodẻ ir dauguma respondentų, vertinančių savo kompiuterinị raštingumą vidutiniškai, nors jų dalis lyginant 2010 ir 2012 m. sumažèjo. 2010 m., kad IKT naudojamos darbo vietoje labai palengvina sveikatos priežiūros paslaugų teikimą, nurode 70,5 proc., 2012 m. - 70,5 proc. vidutiniškai savo kompiuterinị raštingumą vertinančių respondentų (2 pav.).

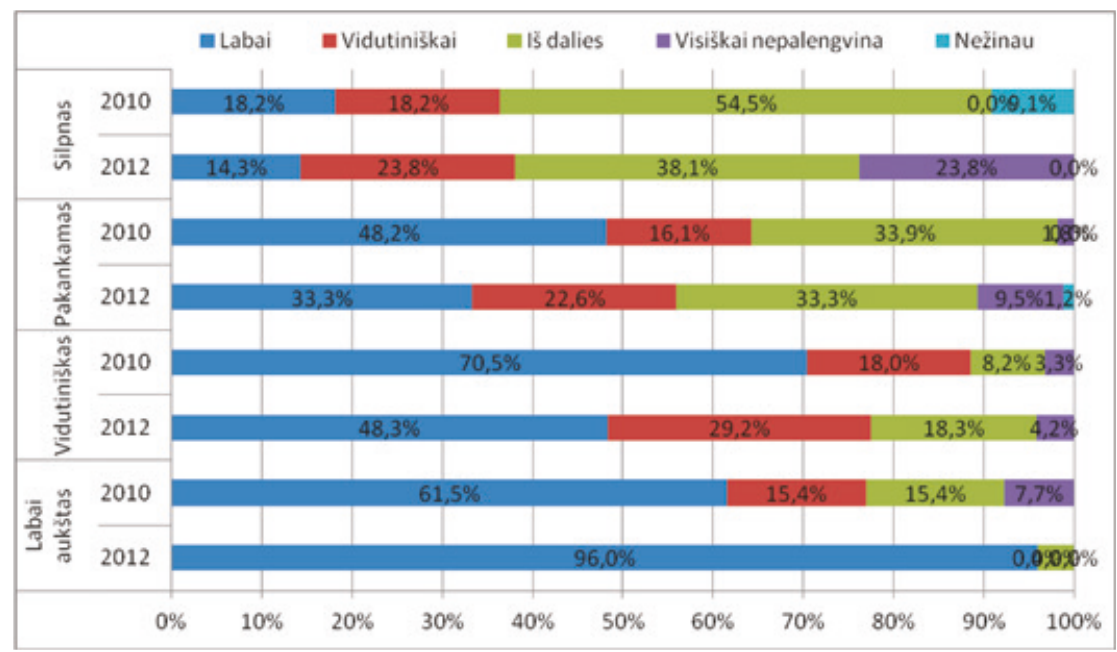

2 pav. Nuomonių, ar naudojimasis IKT palengvina sveikatos priežiūros paslaugų teikimą, pasiskirstymas pagal kompiuterinị raštingumą

Siekiant išsiaiškinti sveikatos priežiūros specialistų nuomonę apie IKT plètrą, darbuotojams užduotas klausimas, ar reikalinga IKT plètra poliklinikoje. Nustatytas statistiškai reikšmingas skirtumas tarp 2010 ir 2012 m. vykdytų apklausų atsakymų. 2010 m., kad IKT plètra yra reikalinga, manė 86,8 proc. respondentų, tuo tarpu $2012 \mathrm{~m}$. taip manè 77,6 proc. respondentų $\left(\chi^{2}=6,503, \mathbf{d f}=\mathbf{2}, \mathbf{p}<\mathbf{0 , 0 5}\right)$.

Vertinant apklausoje dalyvavusių nuomonę, ar reikalinga IKT pletra pagal darbuotojų savo kompiuterinio raštingumo vertinimą, nustatytas statistiškai reikšmingas darbuotojų nuomonių 2010 ir 2012 m. skirtumas, savo kompiuterinị raštingumą vertinusių kaip pakankamą $\left(\chi^{2}=6,690, \mathbf{d f}=\mathbf{2}, \mathbf{p}<\mathbf{0 , 0 5}\right)$.

3 paveiksle matyti, kad darbuotojai, $2010 \mathrm{~m}$. savo kompiuterinị raštingumą vertinę kaip pakankamą, dažniau nurodè, kad IKT plètra poliklinikai yra reikalinga - 78,9 proc. darbuotojų. Tuo tarpu 2012 m., kad IKT pletra poliklinikai yra reikalinga, nurodè 59,5 proc. savo kompiuterinị raštingumą vertinusių kaip pakankamą darbuotojų. 


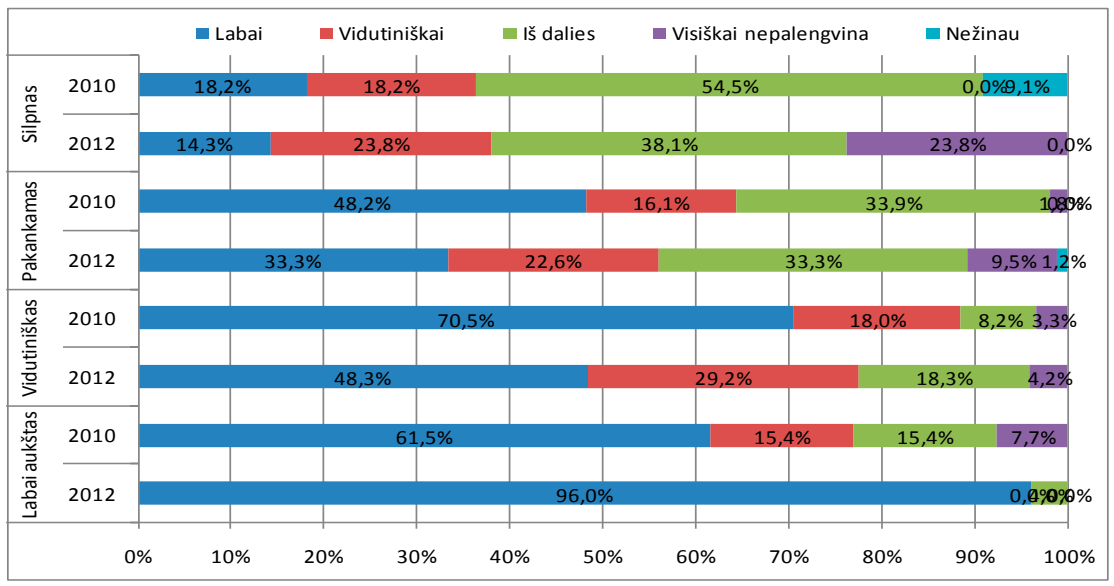

3 pav. Nuomonių, ar reikalinga IKT plètra poliklinikoje, pasiskirstymas pagal darbuotojų kompiuterinị raštingumą

Vertinant apklausoje dalyvavusių darbuotojų nuomonę, ar reikalinga IKT plètra, pagal darbuotojų stažą, nustatytas statistiškai reikšmingas darbuotojų nuomonių 2010 ir $2012 \mathrm{~m}$. skirtumas tarp darbuotojų, turinčių 21 metų ir didesnị darbo stažą $\left(\chi^{2}=7,455, \mathbf{d f}=2, \mathbf{p}<\right.$ 0,05). Lyginant 2010 ir 2012 m. rezultatus, tarp turinčių 21 metų ir didesnị darbo stažą respondentų, manančių, kad IKT pletra yra reikalinga, sumažejo nuo 86,6 iki 72,6 proc. (4 pav.).

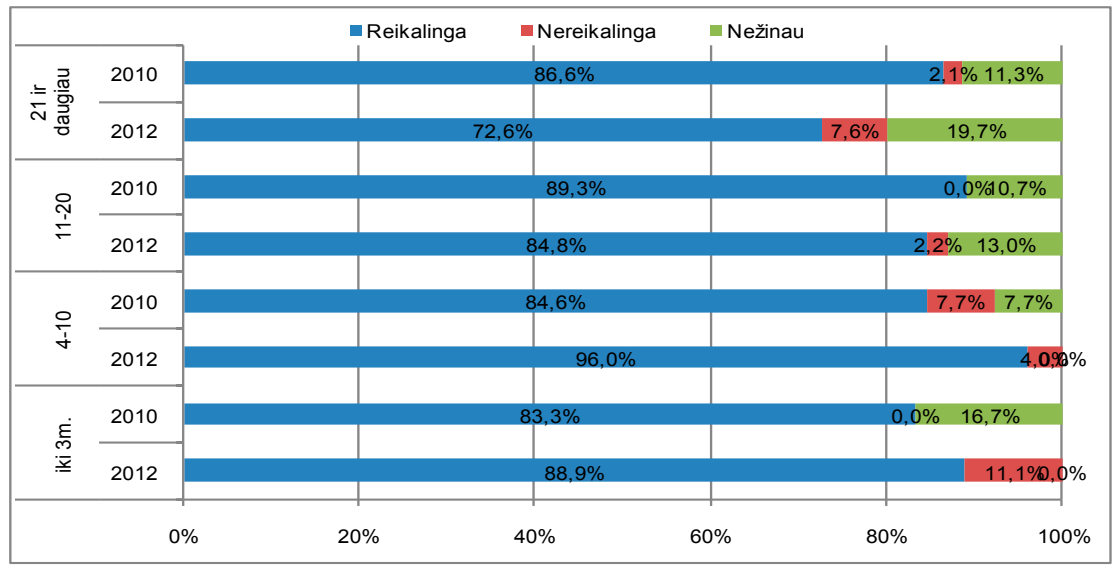

4 pav. Nuomonių, ar reikalinga IKT plètra poliklinikoje, pasiskirstymas pagal darbuotojų stažą

Lyginant Centro poliklinikoje atlikto tyrimo ir $2007 \mathrm{~m}$. Airijoje atlikto tyrimo duomenis dèl darbuotojų atsakymų ị klausimą, ar reikalinga IKT plètra poliklinikoje, pagal darbuo- 
tojų stažą, duomenys iš dalies sutampa. Galima ịžvelgi bendrą tendenciją, tačiau dèl skirtingo darbo stažo skirstymo ị kategorijas dèsningumas nekonstatuojamas. Airijoje atlikto tyrimo išvadose nurodoma, kad darbuotojų, turinčių mažesnę nei 5 metų darbo patirtị, požiūris buvo palankesnis (2012 m. Centro poliklinikoje atliktas tyrimas rodo, kad palankiausiai IKT naudojimą vertina darbuotojai, kurių darbo stažas nuo 4 iki 10 m.). Tuo tarpu ryškiausi skirtumai buvo matomi palyginus darbuotojus, kurių stažas yra 12-18 metų, nepaisant jų patirties sveikatos priežiūros srityje $e^{27}$. Vis dèlto pastebima tendencija, kad didesnị darbo stažą turintys (vyresni) sveikatos priežiūros įstaigų specialistai priešiškesni IKT plètrai.

Siekiant išsiaiškinti darbuotojų, teikiančių asmens sveikatos priežiūros paslaugas, nuomonę apie IKT ịtaką sveikatos priežiūros paslaugų prieinamumui ir kokybei, darbuotojams buvo užduotas klausimai, kaip IKT veikia sveikatos priežiūros paslaugų prieinamumą ir paslaugų kokybę. Nustatytas statistiškai reikšmingas skirtumas tarp 2010 ir 2012 m. vykdytų apklausų atsakymų. $2010 \mathrm{~m}$., kad IKT pagerino sveikatos priežiūros paslaugų prieinamumą ir kokybę, nurodė 57,6 proc. respondentų, tuo tarpu $2012 \mathrm{~m}$. taip manė 35,6 proc. respondentų $\left(\chi^{2}=23,099, \mathbf{d f}=\mathbf{4}, \mathbf{p}=\mathbf{0 , 0 0 1}\right)$. Kad sveikatos priežiūros paslaugų prieinamumą ir kokybę pagerino iš dalies, $2010 \mathrm{~m}$. manè 34 proc., $2012 \mathrm{~m}$. - 43,2 proc. respondentų.

Analizuojant atsakymų i klausimus, kaip IKT veikia sveikatos priežiūros paslaugų prieinamumą ir paslaugų kokybę pagal respondentų savo kompiuterinio raštingumo vertinimą 2010 ir 2012 m., nustatyti statistiškai reikšmingi skirtumai. Nustatyta, kad vidutiniškai vertinantys savo kompiuterinį raštingumą respondentai 2010 m. du kartus dažniau teigè, kad IKT sveikatos priežiūros paslaugų prieinamumą ir paslaugų kokybę pagerino, lyginant su $2012 \mathrm{~m}$. atliktos apklausos duomenimis $\left(\chi^{2}=26,282, \mathbf{d f}=\mathbf{4}, \mathbf{p}=\mathbf{0 , 0 0 1}\right)$. Savo kompiuterini raštingumą kaip pakankamą vertinančių respondentų, kad IKT sveikatos priežiūros paslaugų prieinamumą ir paslaugų kokybę pagerino 2010 m. teigė 40,4 proc., 2012 m. - 25 proc. respondentų $\left(\chi^{2}=10,980, \mathbf{d f}=\mathbf{4}, \mathbf{p}<\mathbf{0 , 0 5}\right)$ (5 pav.).

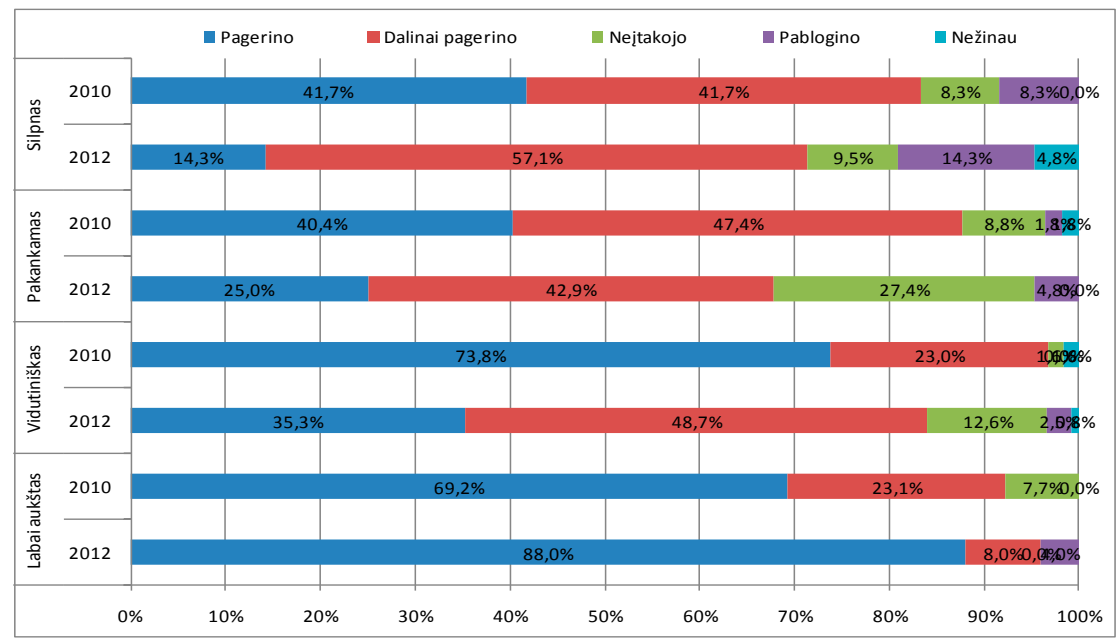

5 pav. Nuomonių, kaip IKT veikia sveikatos priežiūros paslaugų prieinamumą ir kokybę, pasiskirstymas pagal kompiuterinio raštingumo vertinimą

$27 \quad$ Supra note 12. 
Vertinant darbuotojų atsakymus pagal darbo stažą, nustatytas statistiškai reikšmingas skirtumas 21 ir daugiau metų darbo stažą turinčių darbuotojų grupeje. 21 ir daugiau metų darbo stažą turintys darbuotojai 2010 m. apklausoje, kad IKT sveikatos priežiūros paslaugų prieinamumą ir paslaugų kokybę pagerino, nurodè 57,7 proc., tuo tarpu $2012 \mathrm{~m}$. taip mané 28,2 proc. respondentų $\left(\chi^{2}=26,587, \mathbf{d f}=\mathbf{4}, \mathbf{p}=\mathbf{0 , 0 0 1}\right)(6$ pav.).

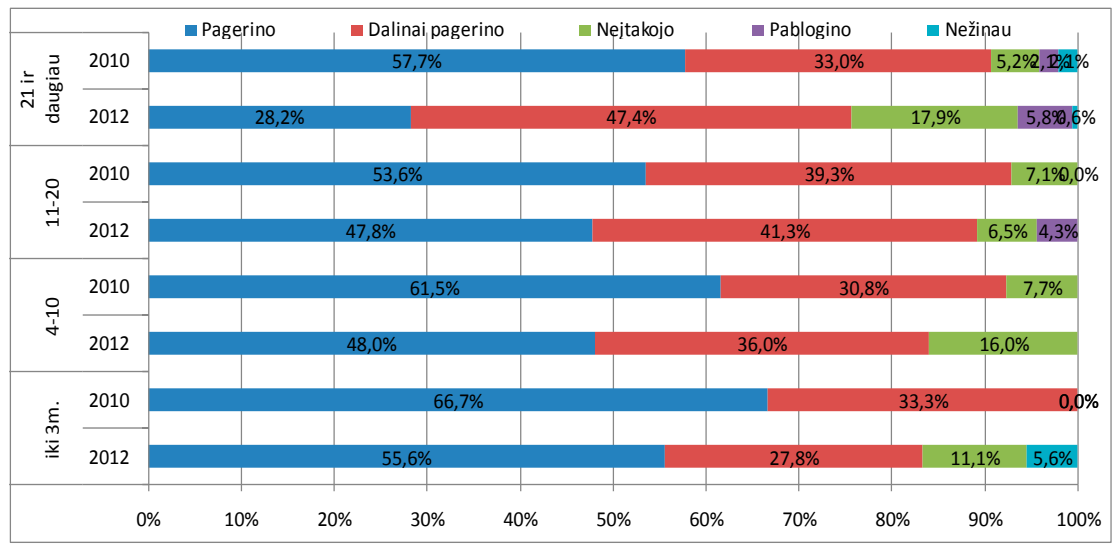

6 pav. Nuomonių, kaip IKT ịtakoja sveikatos priežiūros paslaugų prieinamumą ir kokybę, pasiskirstymas pagal darbuotojų stažą

Analizuojant atsakymų ị klausimus, kaip IKT veikia sveikatos priežiūros paslaugų prieinamumą ir paslaugų kokybę pagal respondentų profesiją / specializaciją 2010 ir $2012 \mathrm{~m}$., nustatyti statistiškai reikšmingi skirtumai slaugytojų grupeje. $2010 \mathrm{~m}$. apklausoje, kad IKT sveikatos priežiūros paslaugų prieinamumą ir paslaugų kokybę pagerino, buvo linkusių manyti 58 proc. slaugytojų, o $2012 \mathrm{~m}$. tokią nuomonę turejjo 39,2 proc. slaugytojų. Beveik 3 kartus, nuo 4,9 proc. $2010 \mathrm{~m}$. iki 15,5 proc. $2012 \mathrm{~m}$., padidejo procentinè dalis slaugytojų, teigiančių, kad IKT sveikatos priežiūros paslaugų prieinamumo ir paslaugų kokybès neveikia $\left(\chi^{2}=26,587, \mathbf{d f}=\mathbf{4}, \mathbf{p}=\mathbf{0 , 0 0 1}\right)(7$ pav. $)$.

2012 m. atliktas tarptautinis tyrimas (Australija, Kanada, Anglija, Prancūzija, Vokietija, Singapūras, Ispanija, JAV), kurio metu buvo apklausti 3700 gydytojai. Tyrimo išvadose, remiantis tyrimo rezultatais, konstatuojama, kad personalui naudojant daugiau e. sveikatos funkcijų palankiau vertinama IKT ịtaka sveikatos priežiūros paslaugų prieinamumui ir kokybei - net 87 proc. šeimos gydytojų, naudojančių 9-12 e. sveikatos funkcijų, mato teigiamą IKT poveikį ${ }^{28}$. Atsižvelgiant ị tai, kad Centro poliklinikoje per dvejų metų laikotarpi (nuo 2010 iki 2012 m.) išaugo ịvairių profesijų / specializacijų specialistų ịstaigoje naudojamų e. sveikatos funkcijų skaičius, daroma išvada, kad nuolatiniai e. sveikatos paslaugų vartotojai yra pozityviau nusiteikę IKT atžvilgiu. Graikijos ${ }^{29}$ darbuotojų, kurie IT naudoja ne darbo metu, požiūris ị naujus technologinius sprendimus darbovieteje pozityvesnis.

\footnotetext{
28 Supra note 10.

29 Vozikis, A.; Ypofanti, M., supra note 11.
} 


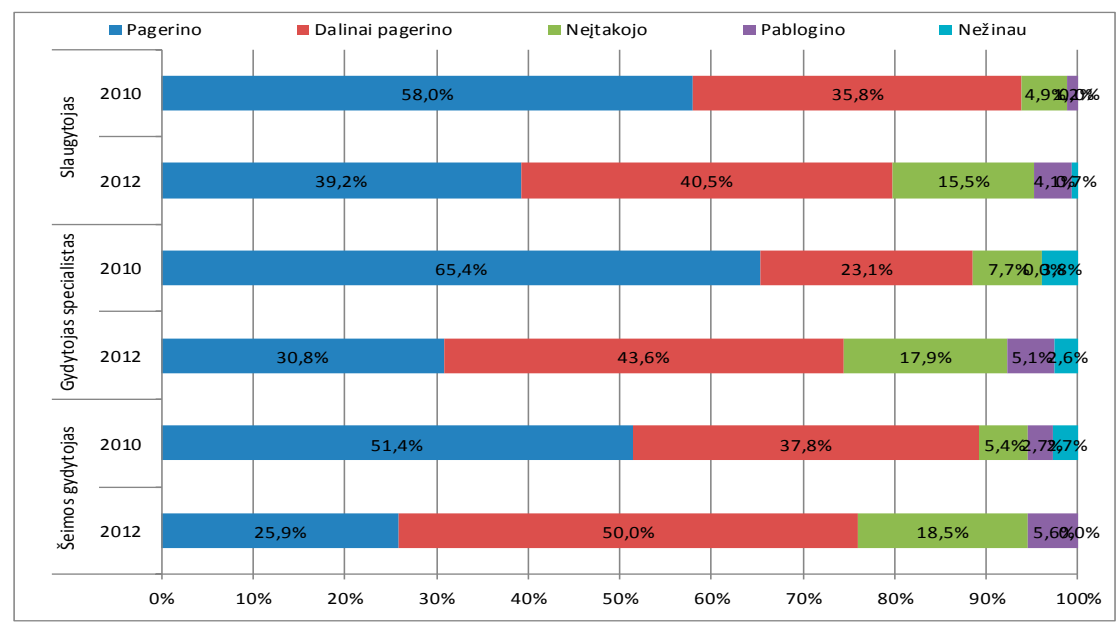

7 pav. Nuomonių, kaip IKT veikia sveikatos priežiūros paslaugų prieinamumą ir kokybę, pasiskirstymas pagal darbuotojų profesiją / specializaciją

Siekiant išsiaiškinti darbuotojų, teikiančių asmens sveikatos priežiūros paslaugas, nuomonę dèl IKT diegimo sveikatos priežiūros įstaigoje svarbos, buvo užduotas klausimas - ar IKT diegimas poliklinikoje turi įtakos renkantis darbovietę. Nustatytas statistiškai reikšmingas skirtumas tarp 2010 ir 2012 m. vykdytų apklausų atsakymų. 2010 m., kad IKT diegimas turi ịtakos renkantis darbovietę, nurode 48,6 proc. respondentų, tuo tarpu $2012 \mathrm{~m}$. taip mané 34,8 proc. respondentų $\left(\chi^{2}=11,005, \mathbf{d f}=\mathbf{2}, \mathbf{p}<\mathbf{0 , 0 1}\right)$.

Analizuojant atsakymus ị klausimus pagal kompiuterinio raštingumo vertinimą $2010 \mathrm{~m}$. ir 2012 m., nustatyti statistiškai reikšmingi skirtumai savo kompiuterinị raštingumą vertinusių kaip labai aukštą ir vidutinišką respondentų grupėse. Nustatyta, kad vidutiniškai savo kompiuterinị raštingumą vertinantys respondentai, nurodę, kad IKT diegimas turi ịtakos darbovietès pasirinkimui, $2010 \mathrm{~m}$. sudare 57,4 proc., tuo tarpu $2012 \mathrm{~m}$. šis rodiklis buvo 32,8 proc. respondentų $\left(\chi^{2}=11,157, \mathbf{d f}=\mathbf{2}, \mathbf{p}<\mathbf{0 , 0 1}\right)$.

Savo kompiuterinị raštingumą vertinusių kaip labai aukštą grupeje, kad IKT diegimas turi ịtakos renkantis darbovietę, $2010 \mathrm{~m}$. nurodè 53, 8 proc., o $2012 \mathrm{~m}$. tik 16 proc. respondentų $\left(\chi^{2}=5,972, \mathbf{d f}=2, \mathbf{p}<\mathbf{0 , 0 5}\right)(8$ pav. $)$. 


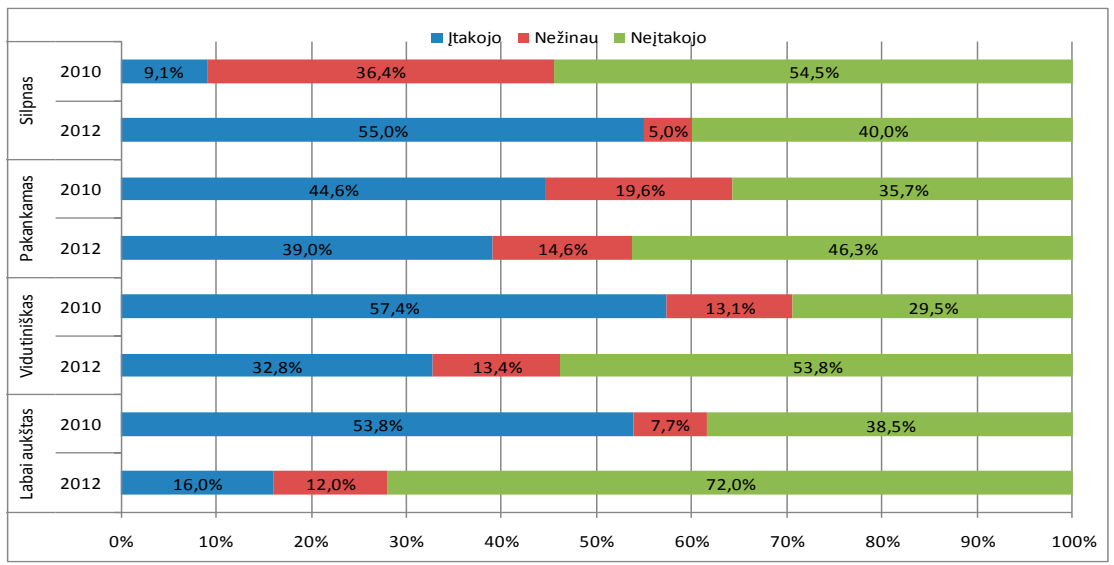

8 pav. Nuomonių, ar informacinių technologijų diegimas poliklinikoje turi ịtakos renkantis darbovietę, pasiskirstymas pagal darbuotojų kompiuterinị raštingumą

Analizuojant atsakymus į klausimus, ar IKT diegimas poliklinikoje turi itakos renkantis darbovietę, pagal profesiją / specializaciją 2010 ir 2012 m., nustatyti statistiškai reikšmingi skirtumai slaugytojų ir gydytojų specialistų grupėse. $2010 \mathrm{~m}$. apklausoje, kad IKT diegimas poliklinikoje turejjo ịtakos renkantis darbovietę, buvo linkusių manyti 51,9 proc. slaugytojų, o 2012 m. tokią nuomonę turejjo 34,7 proc. slaugytojų $\left(\chi^{2}=9,820, \mathbf{d f}=\mathbf{2}, \mathbf{p}<\mathbf{0 , 0 1}\right)$. Gydytojų specialistų grupeje šis skirtumas buvo dar didesnis $\left(\chi^{2}=15,335, \mathbf{d f}=\mathbf{2}, \mathbf{p}=\mathbf{0 , 0 0 1}\right)$ (9 pav.).

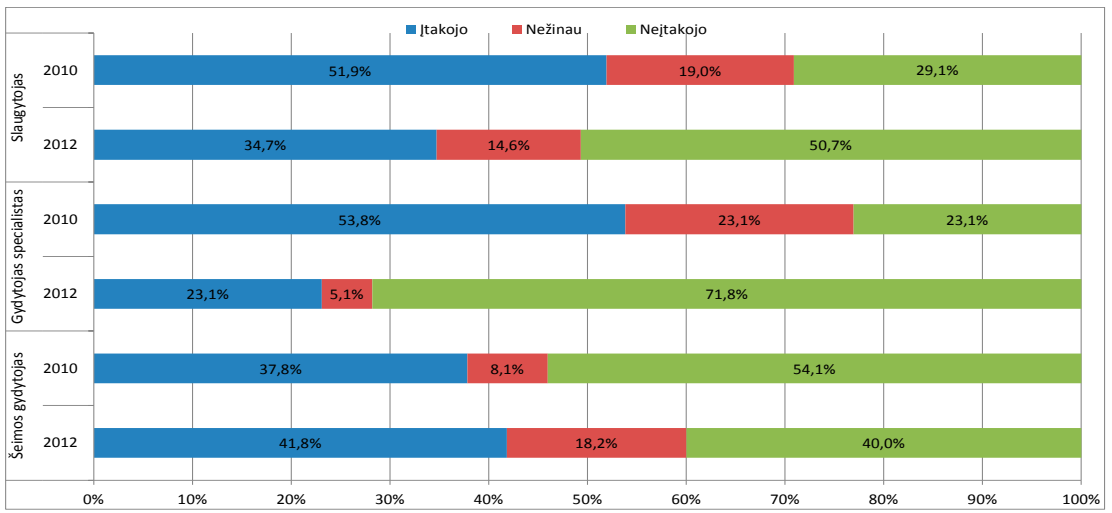

9 pav. Nuomonių, ar IKT diegimas poliklinikoje turejjo ịtakos renkantis darbovietę, pasiskirstymas pagal darbuotojų profesiją / specializaciją

Vertinant darbuotojų atsakymus pagal darbo stažą, nustatytas statistiškai reikšmingas skirtumas iki 3 metų ir 21 ir daugiau metų darbo stažą turinčių darbuotojų grupėse. 21 ir daugiau metų darbo stažą turintys darbuotojai 2010 m. apklausoje, kad IKT diegimas tu- 
rejjo įtakos renkantis darbovietę, nurodè 50,5 proc., tuo tarpu $2012 \mathrm{~m}$. taip manè 41,9 proc. respondentų $\left(\chi^{2}=8,030, \mathbf{d f}=\mathbf{2}, \mathbf{p}=\mathbf{p}<\mathbf{0 , 0 5}\right)$. Iki 3 metų darbo stažą turinčių darbuotojų, $2010 \mathrm{~m}$. teigusių, kad IKT diegimas turèjo ittakos renkantis darbovietę, buvo 66,7 proc., $2012 \mathrm{~m}$. apklausos duomenimis, jų sumažèjo iki 11,1 proc. $\left(\chi^{2}=7,422, \mathbf{d f}=\mathbf{2}, \mathbf{p}=\mathbf{p}<\mathbf{0 , 0 5}\right)$ (10 pav.).

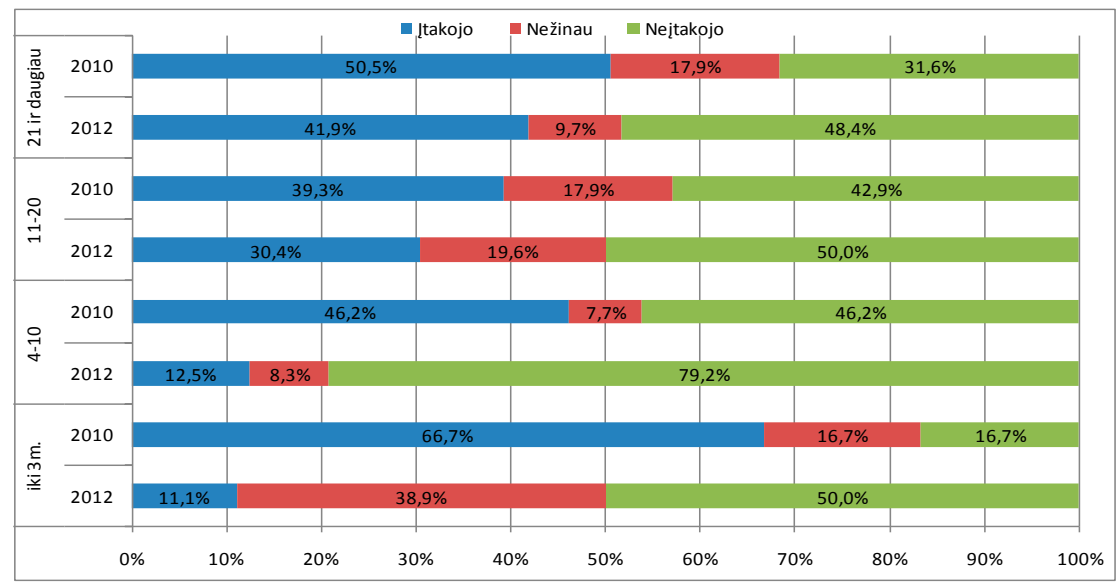

10 pav. Nuomonių, ar IKT diegimas poliklinikoje turejjo įtakos renkantis darbovietę, pasiskirstymas pagal darbuotojų stažą

Atlikus Centro poliklinikoje atliktų apklausų rezultatų analizę ir apibendrinus rezultatus išryškèjo išsamesnių sveikatos priežiūros specialistų nuomonių apie IKT ịtaką sveikatos priežiūros paslaugų teikimui kokybinių tyrimų poreikis.

\section{Išvados}

1. Nepaisant didelių investicijų i̇ IKT, mokslinèje literatūroje nurodomas ịtikinamų įrodymų, kad tokios sistemos naudingos, trūkumas. IKT nauda ir ịtaka sveikatos apsaugos srityje yra sunkiai pamatuojama dèl ịvairių priežasčių. Viena jų - empirinių duomenų trūkumas. Apibendrinus mokslinę literatūrą išskirti šie pagrindiniai faktoriai: respondentų amžius, naudojimosi internetu dažnis, kompiuterinio raštingumo lygmuo ir darbo stažas. IKT plètra sveikatos srityje lemia medicinos paslaugų augimą ir diferenciaciją, o auganti priklausomybė nuo technologinių sprendimų ir automatizuotų sistemų kasdieniniame darbe suponuoja sveikatos priežiūros ịstaigų darbuotojų nuomonių tyrimų poreikį, siekiant išsiaiškinti egzistuojančias problemas ir siūlyti efektyvius sprendimo būdus.

2. Analizė atskleidè, kad sèkmingas IKT pritaikymas priklauso nuo sistemos vartotoju požiūrio, kadangi individualių vartotojų poreikių atitiktis prisideda prie visos organizacijos efektyvumo didinimo. Vienas iš veiksnių diegiant IKT taip pat įvardinamas darbuotojų požiūris, todèl išryškinamas komunikacijos analizès poreikis, kadangi visų suinteresuotųjų pusių ịtraukimas, tiesiogiai susijęs su sveikatos ịstaigos funkcionavimo gerinimu bei klinikinès praktikos tobulinimu, paremtu sąveika. 
3. Lyginant sveikatos priežiūros specialistų nuomonių apie IKT ịtaką sveikatos priežiūros paslaugų teikimui tyrimo Všt Centro poliklinikoje 2010 ir 2012 m. rezultatus, nustatyta, kad IKT plètros poreikis poliklinikoje $2012 \mathrm{~m}$. vertinamas skeptiškiau lyginant su $2010 \mathrm{~m}$. gautais rezultatais. Nustatyta, kad darbo stažas koreliuoja su teigiamu požiūriu ị naudojimąsi IKT. Pastebimas bendras désningumas - nauji darbuotojai, turintys mažesnį darbo stažą, palankiau vertina IKT. Analizuojant atsakymus ị klausimus, kaip IKT veikia sveikatos priežiūros paslaugų prieinamumą ir paslaugų kokybę pagal respondentų profesiją / specializaciją, nustatyti statistiškai reikšmingi skirtumai slaugytojų grupejje. $2012 \mathrm{~m}$. beveik tris kartus padidejo procentinè dalis slaugytojų, teigiančių, kad IKT sveikatos priežiūros paslaugų prieinamumui ir paslaugų kokybei ittakos neturi. Nuolatiniai e. sveikatos paslaugų vartotojai yra pozityviau nusiteikę IKT atžvilgiu. IKT diegimo poliklinikoje įtaka renkantis darbovietę mažèjo visų respondentų nuomone, tačiau statistiškai reikšmingiausi skirtumai nustatyti slaugytojų ir gydytojų specialistų grupèse.

4. Sveikatos priežiūros ịstaigos dèl IKT plètros susiduria su ịvairias iššūkiais, ịskaitant inovatyvaus mąstymo, bendradarbiavimo bei sveikatos ịstaigos narių sinergijos skatinimo būtinybę. Atliktų tyrimų duomenys ir užsienio šalių analogiškų tyrimų rezultatai patvirtina organizacinès komunikacijos svarbą, todèl tikslinga atlikti tolesnị tyrimą ir išsiaiškinti priežastis, kodèl pablogèjo sveikatos priežiūros specialistų nuomonès apie IKT poreikị. Priežastingumo tyrimas padètų suformuluoti vadybinius ir organizacinius sprendimus, leisiančius efektyviau valdyti sveikatos priežiūros organizacijas ir lengvinančius darbuotojų prisitaikymą prie IKT.

Straipsnis parengtas pagal mokslinio tyrimo, finansuojamo Europos socialinio fondo lèšomis pagal visuotinès dotacijos priemonę, medžiaga (projektas „E. sveikatos plètros integruotos tranformacijos: suinteresuotuju pusiu tinklo perspektyva“, projekto kodas VP1-3.1-ŠMM07-K-02-029).

\section{Literatūra}

1. Accenture Connected Health: The Drive to Integrated Healthcare Delivery [interaktyvus]. 2012 [žiūrèta 2013-04-14]. <http://nstore.accenture.com/acn_com/PDF/AccentureConnected-Health-Global-Report-Web.pdf\#zoom=50 <2013 06 01>.

2. Audet, A. M.; Doty, M. M.; Peugh, J.; Shamasdin, J.; Zapert, K; Schoenbaum, S. Information technologies: when will they make it into physicians' black bags? MedGenMed. 2004, 6: 2 .

3. Beuscart, R.; Chazard, E.; Duchêne, J.; Ficheur, G.; Renard, J. M.; Rialle, V.; Souf, N. La e-Santé. Informatique médicale, e-Santé. 2013, p. 437-461.

4. Department of Health, Social Services and Public Safety: ICT Training Group (2007) Knowledge, Skill and Attitude of NI DHSSPS Healthcare Professionals towards Information and Communication Technology: Report of a Northern Ireland Survey. DHSSPS, Belfast [interaktyvus]. [žiūrèta 2013-05-30]. <www.dhsspsni.gov.uk>.

5. Europos Komisija „Commission of the European Communities. E-Health - making healthcare better for European citizens: An action plan for a European e-Health Area“ [interaktyvus]. 2004 [žiūrèta 2013-05-30]. <http://eur-lex.europa.eu/LexUriServ/ LexUriServ.do?uri=COM:2004:0356:FIN:EN:PDF>. 
6. Europos Bendrijų Komisija. Europos pirmaujančios rinkos iniciatyva [interaktyvus]. 2007 [žiūrèta 2013-05-30]. <http://eurex.europa.eu/Notice.do?mode=dbl\&lang=lt\&ihm lang=lt\&lng1=lt,lt\&lng2=bg,cs,da,de,el,en,es,et,fi,fr,hu,it,lt,lv,mt,nl,pl,pt,ro,sk,sl,sv,\&val $=461939: \mathrm{cs}>$.

7. Europos Komisija. eHealth Action Plan 2012-2020 [interaktyvus]. 2012 [žiūrèta 201305-30]. <https://ec.europa.eu/digital-agenda/en/news/ehealth-action-plan-2012-2020innovative-healthcare-21st-century $>$.

8. Europos Komisijos komunikatas Europos Parlamentui, Tarybai, Europos ekonomikos ir socialinių reikalų komitetui ir Regionų komitetui 2012-2020 m. E. sveikatos veiksmų planas. Novatoriška sveikatos priežiūra XXI amžiui [interaktyvus]. 2012 [žiūrèta 201305-30]. <http://eur-lex.europa.eu/LexUriServ/LexUriServ.do?uri=COM:2012:0736:FIN:L T:HTML>.

9. Hammer, M.; Champy, J. Lereengineering. Paris, Dunod, 1993.

10. Hardey, M. Internet et société: reconfigurations du patient et de la médecine ? Sciences sociales et santé. 2004, 22, (22-1): 21-43.

11. Hassenteufel, P. Quelle européanisation des systèmes de santé ? Informations sociales [interaktyvus]. 2013, 1(n 175): 48-59 [žiūrèta 2013-05-30]. <www.cairn.info/revueinformations-sociales-2013-1-page-48.htm>.

12. Hubner, Ur. IT adoption of clinical information systems in Austrian and German hospitals: results of a comparative survey with a focus on nursing. BMC Medical Informatics and Decision Making. 2010, 10(8): 1-12.

13. Institute of Medicine. Crossing the Quality Chasm: A New Health System for the 21st Century. Washington, DC: National Academy Pr; 2001.

14. Legris, P.; Ingham, J.; Collerette, P. Why do people use information technology: A critical review of the technology acceptance model. Information \& Management. 2003, 40: 191-204.

15. Lewis, W.; Agarwal, R.; Sambamurthy, V. Sources of Influences on Beliefs about Information Technology Use: An Empirical Study of Knowledge Workers, MIS Quarterly. 2003, 27(4): 657-678.

16. Lietuvos statistikos departamentas. Informacinès technologijos sveikatos priežiūros istaigose 2011 [interaktyvus]. [žiūrèta 2013-05-30]. < http://web.stat.gov.lt/lt/news/view /?id=9379\&PHPSESSID=twmjcujxideyz $>$.

17. Lorenzo, S.; Mira, J. J. Are Spanish physicians ready to take advantage of the Internet? World Hospitals And Health Services: The Official Journal Of The International Hospital Federation [World Hosp Health Serv]. 2004, 40 (3): 31-35, 41-43.

18. Ndiaye, Diarra. Analyse communicationnelle des systèmes d'information dans le secteur de la santé (2000-2012): l'exemple de l'implantation de deux logiciels dans les pratiques de la clinique mutualiste La Sagesse de Rennes - 2013 [interaktyvus]. [žiūrèta 2013-0530]. <http://tel.archivesouvertes.fr/docs/00/81/81/88/PDF/2013theseNdiayeDpartielle. pdf $>$.

19. Organisation for Economic Co-operation and Development. 2010. Improving Health Sector Efficiency: The Role of Information and Communication Technologies. OECD Health Policy Studies. Paris: OECD Publishing [interaktyvus]. Accessed February 16, 2011 [žiūrèta 2013-05-30]. <http://www.oecd.org/document/61/0,3746, en_2649_33929_45501565_1_1_1_1,00.html>.

20. Poon, Eric. Assessing the level of healthcare information technology adoption in the United States: a snapshot; Medical Informatics and Design. 2006, 6(1). 
21. Pukènas, K. Sportiniu tyrimų duomenų analizé SPSS programa. Kaunas: Lietuvos kūno kultūros akademija, 2005.

22. Rahimi, B. Implementation of Health Information Systems. Linköping Studies in Science and Technology. Thesis. 2008, p. 1387.

23. Grosjean, S.; Bonneville, L. Logiques d'implantation des TIC dans le secteur de la santé. Revue française de gestino [interaktyvus]. 2007, 3(nº 172): 145-157 [žiūrèta 2013-05-30]. <www.cairn.info/revue-francaise-de-gestion-2007-3-page-145.htm>.

24. Smith, M. F. E-Health: Roadmap for 21st Century Health Care Consumers. Paris: Organisation for Economic Co-operation and Development Forum 2004: Health of Nations; 2004.

25. Štaras, K. Informacinių technologijų įtaka sveikatos priežiūros įstaigos veiklos efektyvumui: analize, vertinimas, veiksmingumas. Daktaro disertacija. Socialiniai mokslai. Mykolo Romerio universiteto Leidybos centras, 2011.

26. The Health Information Technology Interactive Database [interaktyvus]. Accessed 17 March 2006 [žiūrèta 2013-05-30]. <http://healthit.ahrq.gov/tools/randon>.

27. Vozikis, A.; Ypofanti, M.; Papadopoulos, I. Attitudes towards the use of information and communication technologies (ICT) at work: Findings from the health care sector in Greece. Journal of Economic and Business. 2010, 60(1-2).

28. Ward, R.; Stevens, C.; Brentnall, P.; Briddon, J. The attitudes of health care staff to information technology: a comprehensive review of the research literature. Health Info Libr J. 2008, 25(2): 81-97.

\title{
Impact of Information and Communication Technologies on Delivery of Health Care Services
}

\author{
Kęstutis Štaras, Monika Mačiulienė, Viktorija Stokaitė \\ Mykolas Romeris University, Lithuania
}

\section{Summary}

This paper analyses the influence of Information and Communication Technologies (ICT) in the delivery of healthcare services in order to find out the opinion of health care professionals. The results of 2010 and 2012 survey in Centre Clinic (Vilnius, Lithuania) are analysed and compared. The research topic is very relevant, given the spread and prevalence of the ICT. It should be noted that the rapid development of the ICT has led to miscellaneous changes (new organizational tools, changes in management practices), which resulted in internal and external transformations in health institutions. Health care institutions are facing various challenges as an outcome of the ICT development, including innovative thinking, collaboration and the need for authorities to foster synergy in health care institutions. Analogical results of foreign researchers confirmed the importance of organizational communication. Due to the influence of technological development on the ways health care institutions are operating, this study is particularly relevant in the light of the need for co-operation and dynamic linkages to organizational processes.

In this paper, methods of literature analysis as well as review of foreign best practices are applied. To collect empirical data, a survey was conducted in Centre Clinic (Vilnius, Lithuania) in 2010 and 2012. In 2010, 144 health care professionals (who used the ICT in their workplace) were surveyed, whereas in 2012, 252 health care professionals were interviewed. Case study 
analysis was made, based on the empirical results. According to their working experience, specialization, and computer literacy, empirical data were compared on these dimensions:

- Influence of the currently used ICT on the quality of health care services;

- Influence of the ICT on the quality and accessibility of health care services;

- Development and spread of the ICT in health care facilities;

- Importance of the ICT used in the facility when applying for a job position.

The paper includes research review and identification of common criteria, which derived from the analysis of scientific literature on the influence of the ICT on health care delivery.

As an outcome of the ICT development, health care institutions are facing various challenges, including lack of innovative thinking, collaboration and synergy between members of organizations. The results of this research and available foreign studies confirmed the importance of organizational communication, therefore, it is recommended to carry out further investigations to find the reasons why the opinion of health care professionals on the ICT has deteriorated.

Keywords: health policy, e-health, information and communication technologies, health care services.

Dr. Kęstutis Štaras, Mykolo Romerio universiteto Socialinès politikos fakulteto Sociologijos katedros docentas. Mokslinių tyrimų kryptys: e. sveikata, informacinių technologijų įtaka sveikatos apsaugos sektoriuje, efektyvus sveikatos paslaugų tiekimas.

Monika Mačiulienè, Mykolo Romerio universiteto Socialinės politikos fakulteto Komunikacijos ir informatikos instituto lektorè. Mokslinių tyrimų kryptys: informacinių technologijų pritaikymas organizacijų valdyme, vertės kūrimas kartu su vartotojais, minios resursai.

Viktorija Stokaitė, Mykolo Romerio universiteto Politikos ir vadybos fakulteto Vadybos instituto doktorantė, lektorè. Mokslinių tyrimų kryptys: švietimo projektų valdymas, socialinių technologijų ịtaka organizacijų veiklos procesams.

Dr. Kęstutis Štaras, Mykolas Romeris University, Faculty of Social Politics, Department of Sociology. Research interests: e-health, ICT impact on sector of health care services, efficient delivery of e-health services.

Monika Mačiulienė, Mykolas Romeris University, Faculty of Social Politics, Institute of Communication and Informatics. Research interests: ICT use in management of organizations, co-creation of value, crowdsourcing.

Viktorija Stokaitè, Mykolas Romeris University, Faculty of Politics and Management, Institute of Management. Research interests: management of education related projects, impact of social technologies on organization management. 